Kelaniya Journal of Human Resource Management

Volume 11, Number 01 - January 2016

DOI: http://doi.org/10.4038/kjhrm.v11i1.27

\title{
Impact of Job Satisfaction on Job Performance of Non-Executive Employees in Hotel Industry: With Reference To Kalutara District
}

\author{
M. D. S. H. Perera ${ }^{1}$ and W. A. S. Weerakkody ${ }^{2}$ \\ ${ }^{1}$ Department of Government Information Sri Lanka \\ ${ }^{2}$ Department of Human Resource Management, University of Kelaniya, Sri Lanka \\ ${ }^{1}$ shperera1@gmail.com, ${ }^{2}$ was@kln.ac.lk,
}

\begin{abstract}
These days all organizations recognized the organizations can gain competitive advantage in market place only if it has employees who possess positive work related attitudes. Job satisfaction is one of the most important attitudinal factor on job performance. This study was made to measure the impact of job satisfaction on job performance of non-executive employees in hotel industry (star hotels) with regard to Kalutara district, Sri Lanka. On the scenario of continuous discussions on challenges faced by hotel industry in Sri Lanka, human involvement is yet to be considered as a significant organizational factor. There are several human resources glitches in hotel industry. It has made a vast impediment to minimize the effort of the achieving organizational objectives in the hotel industry.

The data were collected from a stratified randomly selected sample of 250 non-executive employees in the hotel industry (star hotels) by administrating a structured questionnaire, which consisted of 38 questions/statements with 5 points scale. The data analyses consist of correlation and regression. The findings reveal that, job satisfaction was correlated with job performance of non-executive employees. Also there was an impact of job satisfaction on job performance of non-executive employees. Based on the findings valuable suggestions provided to the managements of hotel industry with regard to Kalutara district Sri Lanka to minimize the existing issues.
\end{abstract}

Keywords: Attitudinal Factors, Job Satisfaction, Job Performance, Hotel Industry, Non-Executive Employees 


\section{Introduction}

Organizations functioning basically with a purpose. If an organization wants to reach its objective in this competitive environment it is necessary to arrange its limited resources according and move towards the objective. Among the resources available in the organization human resource is the vital aspect. It acts as the basic agency for the use of other resources too. If an organization wants to reach its objective through changes in this competitive atmosphere, the human resources available in should be very skillful and dedicated or committed. It is very difficult to achieve the objective of the organization without considering of the human resource act with their, personal goals and desires.

Employee's job performance can be defined as in terms of quantity and quality expected from each employee (Khan et al, 2011). With increase in competition, firms have recognized the importance of the employee's job performance to compete in this global market because as the performance of the employees increases, it will affect organization's performance and ultimately profitability of the whole organization. Job satisfaction describes that how much happy an individual is with his or her job. According to Locke (1976) job satisfaction is a pleasurable or positive emotional state resulting from the appraisal of one's job and job experiences.

Non-executive employees in an organization have been affected by many factors to determine their job performance. Among those, the job satisfaction may be a major root to determine the degree of non-executive employees' effort in an organization (Locke, 1976). In this research the researcher attempted to find out impact of job satisfaction determining the job performance of non-executive employees in hotel industry (star hotels) in Kalutara district Sri Lanka.

\section{Problem Statement}

The execution of the organization be determined on the employees who work for the organization (Moorhead \& Griffin, 1999). Demoralizing employees do not perform their employment well. Job satisfaction of employees have expressive impact on the job performance. Higher level of job satisfaction have emotional impact to make the workforces contented. Happy employees 
perform their employment well. Job satisfaction of non-executive employees in hotel industry with regard to Kalutara district affect job performance. Various studies on job performance and job satisfaction lay down diverse outcomes or results (Moorhead, \& Griffin, 1999). According to this study attempts to find out, "How job satisfaction effect on job performance of nonexecutive employees in hotel industry (star hotels) with regard to Kalutara district, Sri Lanka?".

\section{Research Objectives}

The main research objective of this study was to find out the impact of job satisfaction on job performance of non-executive employees in hotel industry (star hotels) with regard to Kalutara district, Sri Lanka.

\section{Literature Review}

\subsection{Job Performance}

Performance is defined as the degree of accomplishment of particular task, duties and responsibilities for employee to achieve organizational goals. Job performance interest to organizations because of the importance of high productivity in the workplace. As in (Salanova \& Kirmanen, 2008) (Hunter $\&$ Hunter, 1984).Job performance is one of the significant indicators in considering organizational performance. As in (Salanova \& Kirmanen, 2008) (Wall et al., 2004). According to Schermerhorn's definition job performance as quality and quantity achieved by individuals or group after fulfilling a task. As in (Salanova \&Kirmanen, 2008) (Schermerhorn, 1989).Viswesvaran \& Ones (2000), have described job performance as "behaviors and outcomes that employees engage in or bring about that are linked with and contribute to organizational goals". As in (Salanova \& Kirmanen, 2008) (Viswesvaran \& Ones, 2000).

Munchinsky has suggested that job performance is the set of employee's behaviors that can be measured, monitored, and evaluated achievement at individual's level. As in (Salanova \& Kirmanen, 2008) (Munchinsky, 2003).

Historically, job performance was viewed as a single construct but researchers now agree that job performance is multidimensional factor. As in (Salanova \& Kirmanen, 2008) (Austin and Villanova, 1992). To support this, Motowidlo \& Scotter have suggested that job performance should comprise 
of task performance and contextual performance. As in (Salanova \& Kirmanen, 2008) and (Motowidlo \& Scotter 1994).

Task performance covers a person's contribution to organizational performance, refers to actions that are part of the formal reward system i.e., technical core, and addresses the requirements as specified in job descriptions. As in (Barling, 2010) (Wi1liams \& Karau, 1991). Contextual performance consists of behavior and does not directly contribute to organizational performance but supports the organizational, social and psychological environment.

\subsection{Job Satisfaction}

According Henne and Locke (1985) job satisfaction is an emotional response to a value judgment by an individual worker. If his job values are perceived as being fulfilled, he will experience the pleasurable emotions of satisfaction; if they are perceived as being frustrated, he will experience the unpleasable emotion of dissatisfaction. Oslan define job satisfaction as the positive emotional response to a job situation resulting from attaining what the wants and values from the job. Locke has defined job satisfaction as a positive emotional feelings resulting from acceptable evaluation of his or her experience towards the job (Locke, 1976).According to Loke's definition it as " a pleasurable or positive emotional state resulting from the appraisal of one's job or job experiences" (Locke, 1976). Implicit in Locke's definition is the importance of both affect, or feeling, and cognition, or thinking. They are intrinsic and extrinsic satisfaction. According to, Hirschfield intrinsic job satisfaction refers to how people feel toward the nature of the job tasks while extrinsic job satisfaction how they feel about aspects of the work situation that are external to the job tasks. As in (Salanova \& Kirmanen, 2008) (Hirschfield, 2000). Some researches define job satisfaction in terms of feelings, attitudes and beliefs. Robbins (2000) defines job satisfaction as an individual's genera; attitudes to his or her job.

In the organization's point of view good job satisfaction can lead to better performance of the workers which affects the result of the company. Employee satisfaction is generally considered as the driver of the employee retention and employee productivity. Satisfied employees are a precondition for increasing productivity, responsiveness, and quality and customer service. As in (Salanova \& Kirmanen, 2008) (Kaplan, 1996). 


\section{Conceptual Framework}

According to this research non-executive employees' job performances depend on such attitudinal factors .Mainly emphasis on job satisfaction according to this research. Job performance of non-executive employees' considered as the dependent variable. Job satisfaction of non-executive employees' regarded as independent variable according to the study.

\section{Independent Variable}

Job Satisfaction $\longrightarrow$ Job Performance

\section{Figure 01: Conceptual Framework}

\subsection{Hypotheses of the Study}

Based on the research model, the hypothesis there is an impact of job satisfaction on job performance of non-executive employees in hotel industry (star hotels) with regard to Kalutara district, Sri Lanka.

\section{Methodology}

The target population of this study was the non-executive employees in hotel industry (star hotels) with regard to Kalutara district Sri Lanka. All star hotels in the district were selected. All together there were 1250 non- executive employees. Twenty designations includes for the non-executive employee categories. Sample size was $20 \%$ of the whole population. 250 non-executive employees were selected as the sample of this study. The data were collected from stratified randomly selected sample of 250 non - executive employees in the hotel industry (star hotels) by directing a structured questionnaire, which consisted of 38 questions/statements with 5 points scale.

\subsection{Dimensions of Variables}

\subsubsection{Dimensions of Job Performance}

The dependent variable of the research was measured by an instrument consisting of 10 statements. The job performance of non-executive 
employees was measured in terms of three dimensions as traits, behaviors and results (Opatha \& Ismail, 2002) .

\subsubsection{Dimensions and Aspects of Job Satisfaction}

The Independent variable also measured by the questionnaire, which was a standard questionnaire known as Minnesota Satisfaction Questionnaire (MSQ).The shortened version of the MSQ used for this research dimensions. (Dharmawardena, 1998).

\section{Analysis and Results}

Reliability analyzes, sample analyzes, correlation analyzes of the dependent and independent variables and simple regression analyze were done in order to achieve the established objectives and to test hypotheses of the study The internal item consistency reliability was examined with Cronbach's Alpha test. In this study Cronbach's Alpha of job performance was 0.856, job satisfactions' it was 0.991 .

Pearson's Correlation was tested to identify the relationship between job satisfaction and job performance of the non - executive employees in the hotel industry (Star Hotels) in Kalutara district ,Sri Lanka and it was 0.674 which is significant at $1 \%(\mathrm{p}=0.000)$.

According to the regression results of model summary of job satisfaction and job performance, $\mathrm{R}$ Square is 0.365 , which indicates that $36.5 \%$ of the variation in job performance (dependent variable) of non-executive employees in Star hotels in Kalutara district Sri Lanka explained by the job satisfaction .Also it was significant. It indicates that $36.5 \%$ of the variation in job performance (dependent variable) of non-executive employees in hotel industry (star hotels) in Kalutara district Sri Lanka is explained by the job satisfaction (independent variable) alone. Hence the formulated hypothesis was accepted.

\section{Conclusion and Recommendations}

Based on the results, there was somewhat positive relationship between job satisfaction and job performance of non-executive employees. At the same time, there was an impact of job satisfaction on job performance of non- 
executive employees in hotel industry (star hotels) with regard to Kalutara district, Sri Lanka. Following suggestions and recommendations help to improve job satisfaction of non-executive employees for their job performance according to the conclusion.

Suggestions given based on the analysis and findings. Salary, promotion opportunities, work itself, unbiased rewards, mentally challenging work, compassionate working conditions, policies or strategies and procedures ,coworkers, and supervisor's needs, aspirations and institutional benefits are the few ways of upgrading the job satisfaction of an employees. Considering these factors help top managements' of the hotel industry to enhance the job satisfaction of the non-executive employees to gain maximum contribution to achieve the organizational objectives. It will assistance to enhance the job performances of employees.

Following recommendations can be given for this study. It should be improve and maintain the job satisfaction in the hotel industry to enhance the job performance of employees. Instead of continue with current practices, managements of star hotels in Kalutara district Sri Lanka attempt to emphasize the fair and friendly management practices towards non-executive employees.

Managements of the hotels in the district can develop a conductive (helpful) environment to enhance the non-executive employees' job satisfaction by giving due consideration to the main motivational factors which affect job satisfaction. Managements should plan, implement and review attractive motivation and remuneration packages for non-executive employees. Since remuneration is a significant factor for job satisfaction, policies relating to wages and incentive should be fair and clear in the hotel industry. Special attention should be paid on the basic minimum salary increments. Job security since most of the non-executive employees are under contract $(45 \%)$ and casual (14\%) basis. Both contract and casual basis together $59 \%$. Some of non-executive employees employed in this sector assume that time factor for confirmation will be a risk.

According to the Sri Lankan culture, some people think that employment in the hotel industry is not socially acceptable. Hence, psychological dissatisfaction can be seen in the hotel industry. Therefore maintain to get 
social acceptance of those employments is a necessary condition for enhance the job satisfaction of the non-executive employees.

Both management and non-executive employees should develop better attitudes towards each other to accept pleasant labor management relations. Engaging with supportive supervision considering both aspects of task and people. Further, study suggests the following for improving non-executive employees' ability on the basis of hotel industry.

Arrange training programmes for non-executive employees. Responsibility for training should be the concern of the management in regards to planning, budgeting, implementing and reviewing. In addition there should be a strong leadership to give clear direction and support in order to obtain the benefits from training.

Maintaining, the current management practices should be further continued up to a higher standard in the sector as a whole. For the purpose regular formal practices can be implemented as a collective programme and then processed through an identical set of experiences. Further, a greater emphasis should be on recruitment and selection in star hotels, since it is highly uncomplimentary in this industry. Hence developing and their background, giving job recognition and considering the possibility of recruitment within the area should be considered to achievement of higher performance level of nonexecutive employees.

\section{References}

Abdullah, W. (2002). Human resources management : A comprehensive guide.Cape Town: Heinemann Publishers (Pvt) Ltd.

Abedel, H. A. (1980). Effects of higher order need strength on the job performance job satis faction relationship. Personnnel Psychology, 33, 335-347.

Ahmad, H., Ahmad , K., \& Syah, I. A. (2010). Relationship between job satisfaction, job performance attitude towards work and organizational commitment. European journal of social sciences , 18, 257-267.

Brayfield , A. H., \& Crockett, W. H. (1955). Employee attitudes and employee performance. Psychological Bulletin, 52, 396-424. 
Kelaniya Journal of Human Resource Management Volume 11, Number 01 - January 2016

Buchanan, B. (1974). Building organizational commitment : The socialization of managers in work organizations. Administrative Science Quarterly : 19, 533546.

Desseler, G. (1998). Personnel management (4th ed.). New York: PrenticeHall,INC.

Dienhart, J. R., \& Gregoire, M. B. (1993). Job satisfaction,job involvement,job security and customer focus of quick-service restaurant employees. Hospitality research journal, 29-44.

Dunn, D. S. (2001). Statistics and data analysis for the behavioral Sciences. New York: McGraw Hill Higher Education.

Eisenberger, R., Huntington, R., Hutchison, S., \& Sowa, D. (1986). Perceived organizational support. Journal of Applied Psychology, 71, 500-507.

Ejiogu, Aloy M. (1980). Theories of job satisfaction and job performance. University of Hull.

Henne, D., \& Locke, E. (1985). Job dissatisfaction: What are the consequences? International Journal of Psychology, 20(2), 221.

Ivancevich, J. M and Matteson, M .T (2005). The measurement of experienced evidence. Journal of Occupational Behavior, 10, 99-113.

Johns, G. (1996). Organizational behavior: Understanding and managing life at work. Harper Collins College Publishers.

Locke, E. A. (1970). Job satisfaction and performance, a theoritical analysis.Chicago: Sage Publication.

Locke, E. A. (1976). The nature and causes of job satisfaction. In E. A. Locke, Hand book of industrial and organizational Psychology (pp. 1297-1349). Chicago: University press.

Ones, D. O., Viswesvaran, C., \& Schmidt, F. L. (1993). Comprehensive meta analysis of integrity test validities findings and implications for personnel selection and theories of job performance. Journal of Applied Psychology, 78, 679-703.

Opatha, H. P. (2003). Research methods for human resource management, questions and answers. Colombo: Author Publication.

Opatha, H. P., \& Ismail, Z. B. (2002). An empirical investigation of management related contributing to labor management relationship in manufacturing firms in Sri Lanka. N M M S Journal , 74-85. 
Kelaniya Journal of Human Resource Management Volume 11, Number 01 - January 2016

Petty, M. M., Mcgee, G. W., \& Cavender, W. J. (1984). A meta - analysis of the relationships between individual job satisfaction and individual performance. The academy of management journal, 9, 712-721.

Robbins, S. P. (2000) Organizational behavior: Concepts, controversies, and applications. New Jersey: Prentice Hall.

Salanova, A., \& Kirmanen, S. (2008). Employee satisfaction and work motivation. London : Mcgraw hill. 